\title{
CHOLINESTERASES, A TARGET OF PHARMACOLOGY AND TOXICOLOGY
}

\author{
Miroslav Pohanka
}

\author{
Faculty of Military Health Sciences, University of Defense, Trebesska 1575, Hradec Kralove, Czech Republic \\ University Hospital Hradec Kralove, Sokolska 581, Hradec Kralove \\ E-mail: miroslav.pohanka@gmail.com
}

Received: February 24, 2011; Accepted with revision: June 3, 2011

Key words: Acetylcholinesterase/Butyrylcholinesterase/Alzheimer's disease/Myasthenia gravis/Huperzine/Donepezil/ Rivastigmine/Galantamine

Background. Cholinesterases are a group of serine hydrolases that split the neurotransmitter acetylcholine (ACh) and terminate its action. Of the two types, butyrylcholinesterase and acetylcholinesterase (AChE), AChE plays the key role in ending cholinergic neurotransmission. Cholinesterase inhibitors are substances, either natural or man-made that interfere with the break-down of ACh and prolong its action. Hence their relevance to toxicology and pharmacology.

Methods and Results. The present review summarizes current knowledge of the cholinesterases and their inhibition. Particular attention is paid to the toxicology and pharmacology of cholinesterase-related inhibitors such as nerve agents (e.g. sarin, soman, tabun, VX), pesticides (e.g. paraoxon, parathion, malathion, malaoxon, carbofuran), selected plants and fungal secondary metabolites (e.g. aflatoxins), drugs for Alzheimer's disease (e.g. huperzine, metrifonate, tacrine, donepezil) and Myasthenia gravis (e.g. pyridostigmine) treatment and other compounds (propidium, ethidium, decamethonium).

Conclusions. The crucial role of the cholinesterases in neural transmission makes them a primary target of a large number of cholinesterase-inhibiting drugs and toxins. In pharmacology, this has relevance to the treatment of neurodegenerative disorders.

\section{INTRODUCTION}

The cholinergic system is based on the neurotransmitter acetylcholine (ACh), firstly recognized by Loewi in 1920s (ref. ${ }^{1}$ ) and found widely distributed in both central and peripheral nervous systems. The two basic types of acetylcholine receptors in the nervous system and at neuromuscular junctions are: muscarinic acetylcholine receptors $(\mathrm{mAChR})$ and nicotinic acetylcholine receptors (nAChR). Acetylcholine receptors are also found expressed in multiple cells including endothelial and immune system cells ${ }^{2}$.

Cholinesterases are a family of enzymes that katalyse the hydrolysis of $\mathrm{ACh}$ into choline and acetic acid, an essential process allowing for the restoration of the cholinergic neuron. Cholinesterases are divided into two: acetylcholinesterase (AChE; EC 3.1.1.7.) and butyrylcholinesterase (BuChE; EC 3.1.1.8). AChE participates in cholinergic neurotransmission by hydrolyzing acetylcholine. It is expressed in nerve and blood cells. Compared to $\mathrm{AChE}$, the importance of $\mathrm{BuChE}$ is not well understood. $\mathrm{BuChE}$ was known as plasmatic cholinesterase or pseudocholinesterase. Similarly, AChE was called blood, also erythrocytal cholinesterase as its activity remains in the cell mass after blood centrifugation. The name AChE derives from the natural substrate acetylcholine as opposed to $\mathrm{BuChE}$ that has no natural substrate. An absence or mutation of $\mathrm{BuChE}$ leads to a medical condition (see below) that shows itself only in the presence of some drugs (e.g. succinylcholine) and toxins (e.g. cocaine) (ref. ${ }^{3}$ ), due to its ability to split artificial substrates. This review's main focus is on cholinesterases as targets of toxins and drugs. The biochemistry of AChE and BuChE is also discussed. Drugs and toxins are divided in chapters according to target sites.

\section{BUTYRYLCHOLINESTERASE}

Though BuChE activity is prevalent in the human body, its' physiological function is not completely understood. BuChE deficient individuals are generally healthy with no manifest signs of disease ${ }^{4}$. The case is similar for mice with a damaged $\mathrm{BuChE}$ gene $\mathrm{e}^{5,6}$. BuChE deficient individuals have increased sensitivity to muscle relaxants such as succinylcholine, resulting in lasting breath insufficiency ${ }^{7}$. Peoples with the deficient, $\mathrm{K}$ type BuChE have lower plasma activity as well as lower affinity for succinylcholine ${ }^{8}$. The $\mathrm{K}$ allele is widely-spread especially in the Caucasus area. In recent publications, a link between $\mathrm{K}$ type BuChE and lower incidence of Alzheimer's disease has been described ${ }^{9}$ However, more research is needed to examine this connection. Regular BuChE is sensitive to inhibition caused by dibucaine (or cinchocaine in some sources) whereas $\mathrm{AChE}$ and $\mathrm{K}$ type $\mathrm{BuChE}$ are relatively resistant to dibucaine. Biochemical examination of $\mathrm{K}$ type $\mathrm{BuChE}$ is based on serum/plasma BuChE assessment with and without dibucaine. The output is called a dibucaine number (DN). This represents the percentage of inhibited BuChE. People with regular BuChE have a high dibucaine number $(\mathrm{DN} \geq 75)$, heterozygotes have medial 
inhibition of $\mathrm{DN} \sim 40-70$, and $\mathrm{K}$ type homozygotes have nearly non-inhibited BuChE (DN < 20) $\left(\right.$ ref..$\left.^{10}\right)$.

In comparison with $\mathrm{AChE}, \mathrm{BuChE}$ is not constituted in situ but in different organs, mainly in the liver ${ }^{11}$. BuChE reaches serum levels of $5 \mathrm{mg} / \mathrm{ml}$ with a half time of 12 days $^{12}$. Assay of BuChE activity in plasma can also serve as a liver function test. BuChE activity decreases until complex liver necrosis occurs. However, the importance of $\mathrm{BuChE}$ as a liver function marker is limited by low sensitivity. Genetic aspects (see above) or intoxication with some compounds such as organophosphate pesticides and/or organophosphonate nerve agents (see below) are sources of false positive findings. BuChE is capable of detoxifying a large number of exogenous substances: procaine $^{13}$, succinylcholine ${ }^{14}$, cocain $\mathrm{e}^{15}$, heroin, acetylsalicylic acid $^{16}$, and it can also protect the body from the impact of organophosphorus $\mathrm{AChE}$ inhibitors ${ }^{17}$. However the primary reason for the existence of $\mathrm{BuChE}$ is still unknown.

As mentioned, BuChE, is named according to its preference for the artificial substrate butyrylcholine. BuChE can split butyrylcholine with higher turnover number than $\mathrm{AChE}$. BuChE is also able to hydrolyze much slower than $\mathrm{AChE}$, indole derivatives ${ }^{18}$, adipoylcholine ${ }^{19}$, benzoylcholine $\mathrm{e}^{20}$, acetylcholine/acetylthiocholine $\mathrm{e}^{21,22}$, butyrylcholine/ butyrylthiocholine $\mathrm{e}^{23,24}$ and propionylcholine/propionylthiocholine $\mathrm{e}^{25,26}$. On the other hand, BuChE is not able to split acetyl- $\beta$-methyl-thiocholine oracetyl- $\beta$-methyl-choline ${ }^{27,28}$ whereas AChE can. A summary of substrates and reaction products is depicted below (Table 1).

The fact that BuChE has wider substrate specificity than AChE is structurally determined. BuChE is a tetrameric glycoprotein composed of four subunits. Both dimeric and monomeric forms are stable and ubiquitous in the body ${ }^{29}$. All subunits are identical and composed of 574 amino acids with an overall molecular weight close to $85 \mathrm{kDa}$. As described by Lockridge et al. ${ }^{30}$ the structural similarity to AChE is $54 \%$ and to bovine thyroglobuline $28 \%$, which leaves ample differences: $\mathrm{BuChE}$ is not in- hibited by substrate excess as is typical for AChE (ref. ${ }^{31}$ ), the active site is wider for $\mathrm{BuChE}$ (ref. ${ }^{32}$ ), $\mathrm{BuChE}$ is sensitive to inhibition by tetraisopropyl pyrophosphoramide (iso-OMPA; see text about AChE), and the inhibition is considered to be a fast proof whether a sample contains BuChE or AChE.

\section{ACETYLCHOLINESTERASE}

$\mathrm{AChE}$ and $\mathrm{BuChE}$ are similar, resembling each other by more than $50 \%$ but their significance and localization in the body are very different. AChE is expressed in cholinergic neurons. Relatively high AChE activity can also be found in blood cells responsible for the degradation of plasma acetylcholine ${ }^{33}$. The primary function of $\mathrm{AChE}$ is rapid splitting of acetylcholine and terminating cholinergic neurotransmission. Individuals with inhibited AChE or knock out AChE mice have over-stimulated acetylcholine receptors ${ }^{34}$. Although, AChE deficient mice are viable, they have reduced musculature with changed morphology ${ }^{35}$ and levels of extracellular acetylcholine nearly sixty times higher than normal. It seems that $\mathrm{BuChE}$ is able to partially recover the AChE missing activity in the deficient animals ${ }^{36}$.

The structure of AChE has been extensively investigated since the 1990s. The first experiments were conducted on AChE in the electric eel (Torpedo californica) due to its availability ${ }^{37}$. This was also considered an informal model until the commercialization of human recombinant AChEs. The AChE active site as well as the whole AChE structure is evolutionary conservative and it contains common regions similar to the other serine hydrolases. Cholinesterases are a type $\alpha / \beta$ hydrolase folded with an $\alpha$ helix bound with $\beta$ sheet that contains a catalytic domain ${ }^{38}$ with catalytic triad Ser - His - Glu, the same as in $\mathrm{AChE}, \mathrm{BuChE}$, and lipases. A similar structure can be also found in carboxyesterases where glutamate is re-

Table 1. Selected substrates and products of AChE respectivelly BuChE catalyzed hydrolysis.

\begin{tabular}{|c|c|c|c|}
\hline Substrate & Product & Enzyme & Reference \\
\hline Succinylcholine + water & succinate + choline & BuChE & 14 \\
\hline Adipoylcholine + water & adipoate + choline & BuChE & 19 \\
\hline Benzoylcholine + water & benzoiate + choline & BuChE & 20 \\
\hline Acetylcholine + water & acetate + choline & $\mathrm{AChE}>\mathrm{BuChE}$ & 21 \\
\hline Acetylthiocholine + water & acetate + thiocholine & $\mathrm{AChE}>\mathrm{BuChE}$ & 22,67 \\
\hline Butyrylcholine + water & butyrate + choline & $\mathrm{BuChE}>\mathrm{AChE}$ & 23 \\
\hline Butyrylthiocholine + water & butyrate + thiocholine & $\mathrm{BuChE}>\mathrm{AChE}$ & $24,61,67$ \\
\hline Propionylcholine + water & propionate + choline & $\mathrm{BuChE}, \mathrm{AChE}$ & 25 \\
\hline Propionylthiocholine + water & propionate + thiocholine & $\mathrm{BuChE,} \mathrm{AChE}$ & 26,67 \\
\hline Acetyl- $\beta-$-methyl-thiocholine + water & $\beta$-metyl-thiocholine + acetate & $\mathrm{AChE}$ & 27 \\
\hline Acetyl- $\beta$-methyl-choline + water & $\beta$-methyl-choline + acetate & $\mathrm{AChE}$ & 28 \\
\hline
\end{tabular}


placed by aspartate ${ }^{39}$. Serine is a part of a stable sequence Gly-Glu(His)-Ser-Gly-Ala/Gly ( ref. $^{40}$ ).

The electric eel AChE's active site lies on a bottom of long and narrow cavity $20 \AA$ deep. The active site contains a catalytic triad within an esteratic site with amino acid positions for the electric eel AChE: Ser 200, His 440 and Glu 327 (ref. ${ }^{41}$ ). The anionic site (also $\alpha$-anionic site) is another part of the active site and it is close to the esteratic site. The anionic site is composed of the amino acids Trp 86, Tyr 337 and Phe 338 for murine AChE $\left(\right.$ ref. $^{42}$ ) or Trp 84, Tyr 121 and Phe 330 for the electric eel $\mathrm{AChE}$ (ref. ${ }^{43,44}$ ). While the esteratic site hydrolyzes the ester bond, the anionic site interacts with the acetylcholine quaternary ammonium atom and is responsible for its correct orientation. Entry into the active site through the cavity composed of aromatic amino acids, i.e. aromatic gorge, enables higher selectivity for acetylcholine. Substrate penetration is allowed by cation $-\pi$ interactions between acetylcholine quaternary ammonium atom and $\pi$ electrons of phenylalanine, tryptophan and tyrosine aromatic cores ${ }^{45,46}$.

The peripheral anionic site (also $\beta$-anionic site) is localized on the AChE surface around the cavity entrance. This site was recognized as a target for multiple AChE activity modulators and the first experiments began in the 1960s (ref. ${ }^{47}$ ). The aromatic site contains loops and it has good conformational flexibility. Tyr 70, Asp 72, Tyr 121, Trp 279 and Tyr 334 amino acids residues are the most significant residues in the peripheral anionic site ${ }^{48}$. As described in the following chapters, the peripheral anionic site is a target for a number of toxins and also promising drugs $\mathrm{s}^{49,50}$. It probably plays an important role in the development of Alzheimer's disease. Amyloid $\beta$ peptide interacts with the peripheral anionic site resulting in the formation of amyloid plaques and consequent damage to cholinergic neurons ${ }^{51}$.

Both AChE and BuChE form mainly tetramer G4 but they can also form dimmer $\mathrm{G} 2$ that can be secreted as a water soluble molecule ${ }^{52}$. Monomeric AChE has molecular weight of $69 \mathrm{kDa}\left(\right.$ ref. $\left.^{53}\right)$. The predominant part of AChE localized in the central nervous system contains botgh hydrophilic and hydrophobic regions i.e. it is amphiphilic. There are differences between amphiphilic and non-amphiphilic cholinesterases. The amphiphiphilic cholinesterase contains G4 catalytic tetramer and one non-catalytic subunit $\mathrm{P}$ (ref. ${ }^{54}$ ). The $\mathrm{P}$ subunit has a molecular weight $20 \mathrm{kDa}$ and it is asymmetrically bound to two $\mathrm{G}$ subunits. From a chemical point of view, it is glycophosphatidylinositol (GPI) called GPI anchor (ref. ${ }^{55,56}$ ). In the human AChE, the liphophilic part of the GPI anchor is palmitate ${ }^{57}$. The biological role of individual AChE forms can be ascertained from an experiment done on monkey brains ${ }^{58} .85 \%$ of $\mathrm{AChE}$ are tetramers with a sedimentation constant $9.7 \mathrm{~S}, 10 \%$ is dimeric (5.7 S) and $5 \%$ monomeric $(3.2 \mathrm{~S})$. In total, $83 \% \mathrm{AChE}$ molecules are amphiphilic and only $17 \%$ hydrophilic. Besides free and membrane bound $\mathrm{AChE}$, there is also collagen bound $\mathrm{AChE}$. From the symbols introduced by Massoulie and Bon, bound $\mathrm{AChE}$ is abbreviated $\mathrm{AChE}_{\mathrm{T}}$ and one collagen oligomer is connected with one $\left(A_{4}\right)$, two $\left(A_{8}\right)$ or three $\left(\mathrm{A}_{12}\right)$ tetrameric $\mathrm{AChE}$ molecules ${ }^{59,60}$.

$\mathrm{AChE}$ and $\mathrm{BuChE}$ have different abilities to split substrates. Compared to BuChE, AChE is not able to hydrolyze high molecular weight esters butAChE has higher affinity for acetylcholine and BuChE for butyrylcholine. The differences in affinity to substrate are probably caused by changes in the aromatic gorge disposition. Substitution of two phenylalanines to leucine and valine in the electric eel AChE aromatic gorge possessed butyrylcholine turnover rate at a similar level to BuChE. Further, mutated AChE was sensitive to inhibition by iso-OMPA and was not inhibited by propidium, a peripheral anionic site inhibitor ${ }^{61}$. Differences in $\mathrm{AChE}$ and $\mathrm{BuChE}$ structures are revealed by huperzine A. This Alzheimer's disease drug is a strong AChE inhibitor binding to the peripheral anionic site; however, BuChE intacts in the presence of huperzine ${ }^{62}$. Another Alzheimer's disease drug, tacrine, binds into the $\alpha$-anionic site. It inhibits $\mathrm{AChE}$ as well as $\mathrm{BuChE}$ to a comparable degree ${ }^{63}$. A similar situation to tacrin is common for other drugs containing quaternary ammonium, nerve agents, and neurotoxic pesticides ${ }^{64-67}$. The basic parameters for $\mathrm{AChE}$ and $\mathrm{BuChE}$ are summarized below (Table 2).

Table 2. Basic parameters of $\mathrm{AChE}$ and BuChE.

\begin{tabular}{|l|c|c|c|}
\hline & AChE & BuChE & References \\
\hline Subunit & $69 \mathrm{kDa}$ & $85 \mathrm{kDa}$ & $29,30,53$ \\
\hline Quaternary structure & \multicolumn{2}{|c|}{$\begin{array}{c}\text { Tetramer predominate, mono-, di- } \\
\text { and trimeric forms can also occur }\end{array}$} & $29,54,55,66,68,69$ \\
\hline Conversion of acetyl- $\beta$-methyl-(thio)choline & High & low & $27,28,71,72$ \\
\hline Inhibition by excess of substrate & Yes & yes & $68,69,70$ \\
\hline Inhibition by iso-OMPA* & No & yes & 65,75 \\
\hline Inhibition by nerve agents & Yes & no & 62 \\
\hline Inhibition by huperzine & Yes & & 65 \\
\hline
\end{tabular}

*Iso-OMPA: tetraisopropyl pyrophosphoramide 
Apropos AChE enzymology, there are differences between $\mathrm{AChE}$ and BuChE. Inhibition by excess of substrate is probably the most important fact ${ }^{68,69}$. The biological significance of AChE inhibition by substrate excess has not yet been proven. One theory however looks feasible ${ }^{70}$. After acetylcholine vesicles are released into the neurosynaptic cleft, $\mathrm{AChE}$ is inhibited and the receptors are stimulated. The termination signal, which has a square plot in cholinergic nerves, is fast once the ACh level drops below threshold concentration. The basic biochemical test for estimating whether a sample contains $\mathrm{AChE}$ and not $\mathrm{BuChE}$ is based on assessment of acetylthiocholine and acetyl- $\beta$-methyl-thiocholine as fast conversion in low concentrations of substrate and slow conversion in high concentration ${ }^{71,72}$ Specific inhibitors introduced later are also applicable. Non-enzymatic functions of $\mathrm{AChE}$ are probable and the research is on-going. Interestingly, body growth and cell adhesion are probably partially connected with AChE (ref. ${ }^{73,74}$ ).

\section{CHOLINESTERASE INHIBITORS}

Cholinesterase inhibitors (e.g. drugs, natural toxins, pesticides, chemical warfare agents) are a wide group of chemical compounds with different physico-chemical properties. AChE inhibitors play a significant role in the biochemical processes of the human body due to the physiological importance of AChE. Specific BuChE inhibitors, such as iso-OMPA (Fig. 1), have mainly diagnostic importance ${ }^{75}$. Lower interest in BuChE inhibitors can be explained by probable BuChE physiological redundancy. For example, drugs suppressing the manifestation of Alzheimer's disease through impact on the cholinergic system are predominantly selective inhibitors of AChE $\left(\right.$ ref. $\left.^{76}\right)$. Selective inhibitors of BuChE have also been investigated as potential drugs for Alzheimer's disease ${ }^{77}$; but to a lesser degree than AChE. Inhibition of AChE also plays an important role in nerve agent toxicology. Intact $\mathrm{BuChE}$ however can temporarily substitute inhibited $\mathrm{AChE}$ and is able to slowly hydrolyze accumulated acetylcholine $^{78}$.

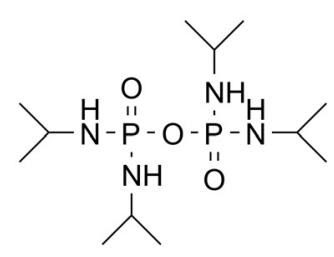

Fig. 1. Tetraisopropyl pyrophosphoramide (iso-OMPA).

Compounds inhibiting $\mathrm{AChE}$ can be divided into three basic groups ${ }^{79}$ :

1. Compounds binding at the active site interact with either esteratic (e.g. nerve agents) or anionic site (e.g. tacrine).

2. Compounds interacting with the aromatic gorge (e.g. decamethonium).
3. Compounds bound at the peripheral ( $\beta$ ) anionic site (e.g. huperzine, propidium).

\section{Inhibitors binding at the esteratic part of active site}

Inhibitors of the esteratic part found on the active site are compounds with the chemical structure of organophosphorus or carbamate derivatives. Inhibitors of esteratic subsite of the active centre are mainly toxins, chemical warfare agents or pesticides. Of course some are used as drugs. These compounds interact with serine in the catalytical triad of active site, providing stable esters. Organophosphorus compounds create stable, covalently bound adducts with spontaneous dissociation once covalently connected with serine hydroxyl. Some drugs containing the oxime group are able to split organophoshorus moiety from the active site resulting in liberation and enzyme reactivation. Obidoxime, trimedoxime, pralidoxime (2-PAM) and asoxime (HI-6) can be mentioned as commercially available drugs ${ }^{3}$. After a specific time interval (from minutes up hours) for each organophosphorus inhibitor, the bound inhibitor undergoes dealkylation called "aging" (ref. ${ }^{80}$ ). The aging has no beneficial effect on the enzyme as it remains inactive. In comparison with organosphosphorus inhibitors, the carbamate moiety is spontaneously hydrolyzed and liberated. AChE becomes active again. Carbamates are probably able to bind through non-covalent interactions ${ }^{81}$. The mechanism of AChE inhibition by an organophosphonate is depicted below (Fig. 2).

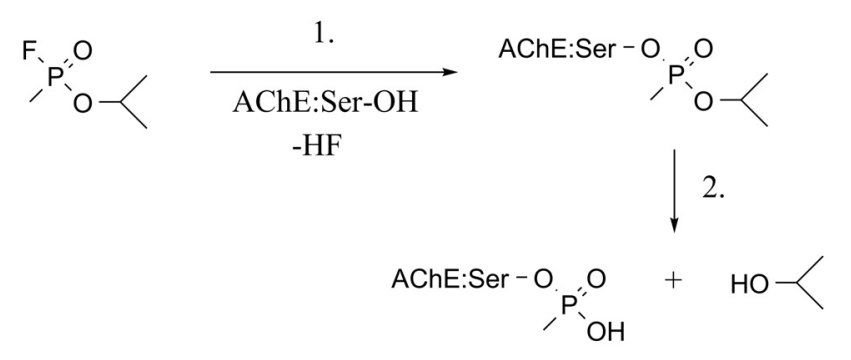

Fig. 2. Inhibition of $\mathrm{AChE}$ by nerve agent sarin (reaction 1) and the consequent aging (reaction 2). Serine hydroxyl is indicated in AChE molecule by an abbreviation (Ser-OH).

Nerve agents are organophosphonate compounds used in chemical warfare. The older group of nerve agents called G series was discovered before World War II. Tabun was the first known nerve agent first synthesized in 1936 by professor Gerhard Schrader. After World War II, the most toxic nerve agents called the $\mathrm{V}$ series were extensively investigated ${ }^{82}$. Tabun (abbreviated GA according to NATO), sarin (GB), soman (GD) and cyclosarin (GF) are representatives of the $G$ series nerve agents. Among VX nerve agents are the Russian VX (VR) and Chinese (VC) variants ${ }^{83}$. The chemical structures of selected nerve agents are depicted in (Fig. 3). 


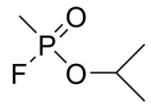

$\operatorname{sarin}(\mathrm{GB})$

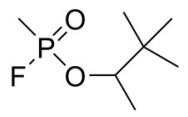

soman (GD)

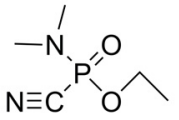

tabun (GB)

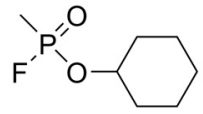

cyclosarin (GF)

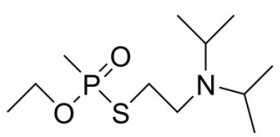

VX

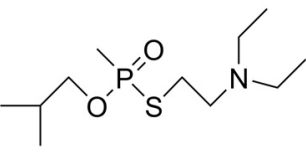

VR

Fig. 3. Selected nerve agents.

Nerve agents are extremely hazardous due to superior penetration ability into the human body by all routes and their high toxicity. Nerve agents differ from pesticides in their toxicity and rapid bodily dissemination The median lethal dose $\left(\mathrm{LD}_{50}\right)$ is different for individual nerve agents: e.g. for subcutaneous administrations to rat, the $L_{50}$ are $193 \mu \mathrm{g} / \mathrm{kg}$ for tabun, $103 \mu \mathrm{g} / \mathrm{kg}$ for sarin, $75 \mu \mathrm{g} / \mathrm{kg}$ for soman, and $12 \mu \mathrm{g} / \mathrm{kg}$ for VX (ref. ${ }^{8486}$ ). Median lethal concentration and time $\left(\mathrm{LCt}_{50}\right)$ in rats for sarin is $150 \mathrm{mg} / \mathrm{m}^{3}$ for ten minutes lasting inhalation ${ }^{87}$. The toxicity of nerve agents is much more apparent than standard pesticides: e.g. the commercially available organophosphate pesticide primiphos-methyl (e.g. preparation Actellic 50EC) has a declared $\mathrm{LD}_{50}$ for rat males and per oral administration $\geq 1,500 \mathrm{mg} / \mathrm{kg}$.

The $\mathrm{G}$ series of nerve agents penetrate the body by all routes and spread quickly through the organism. In comparison with $\mathrm{G}$ series, the $\mathrm{V}$ series of nerve agents are able to penetrate via the lungs and skin with ease; however, $\mathrm{V}$ agents create sub-epithelial reservoirs and the agent is slowly released from the reservoirs ${ }^{88}$. It should be emphasized that nerve agents as well as organophosphate and carbamate pesticides are quite reactive. Apart from binding to $\mathrm{AChE}$ and $\mathrm{BuChE}$, they can bind to multiple organs and tissues in the body. Inhibition of AChE is the most crucial from the toxicological point of view whereas from the therapeutic point of view the most significant fact is the inhibition of carboxylesterase 1. Carboxylesterase 1 is able to recover its activity even after sarin inhibition. This fact encourages scientists in the search for an effective scavenger that would serve as a prophylactic against nerve agent intoxication ${ }^{89}$. The other effective enzyme is serum paraoxonase (PON). The PON is able to split organophosphate and thereby detoxify the poisoned person. On the other hand, PON activity is quite low and fluctuates greatly in the general population ${ }^{90}$.

The less toxic variant of organophosphonate nerve agents are organophosphate pesticides. Highly toxic organophosphate pesticides are e.g. paraoxon ethyl, paraoxon methyl, and malaoxon. These compounds are approximately equally toxic to warm-blooded as well as cold-blooded organisms. Due to the effort to enhance pes- ticide specificity, numerous derivatives of highly toxic pesticides have been prepared to reduce the toxicity towards warm-blooded organisms and retain toxicity to insects. Thioforms of organophosphates such as parathion ethyl, parathion methyl and malathion are some relevant examples. The thioforms of organophosphate pesticides are converted into the above mentioned oxoforms by mixed function oxidases (MFO). The activation proceeds in cold-blooded organisms but this is not common in warmblooded organisms where no metabolizing or dealkylation into non toxic compound take place ${ }^{91}$.

Carbamates are the second group of pesticides inhibiting cholinesterases. From the chemical point of view, they are $\mathrm{N}$-alkyl and $\mathrm{N}, \mathrm{N}$-dialkyl carbamates. The natural derivate of carbamate is physostigmine. It is produced as a secondary metabolite in the African plant Physostigma venenosum (Fabaceae). Physostigmine is a strong reversible inhibitor of AChE. It has broad use in Myasthenia gravis treatment as it increases acetylcholine levels in the damaged neurosynaptic clefts and also as a prophylactic to nerve agent exposure as it blocks the irreversible binding of nerve agents ${ }^{92,93}$. Carbamates are pseudoirreversible inhibitors of cholinesterases; the carbamoyl moiety can be split from cholinesterase by spontaneous hydrolysis ${ }^{94}$. Carbamates cannot penetrate the blood brain barrier in the healthy body; however, stress conditions can enhance diffusion into the central nervous system $^{95}$. Organophosphate and carbamate compounds are not only used in agriculture but for medical purposes too. Rivastigmine is a drug available for the symptomatic treatment of Parkinson's as well as Alzheimer's disease ${ }^{96}$. Trichlorfon (metrifonate) has similar application in medicine to rivastigmine though it was used as a pesticide in the past ${ }^{97}$.

The majority of countries have strong regulations on the application of pesticides; e.g. in the European Union it is regulated by the directive $91 / 41 /$ EHS. Individual preparations are approved for commercialization and the list is regularly updated. Commonly used and relatively safe for warm-blooded organisms, are mainly pesticides: organophosphates - chlorpyrifos, fenitrothion, pirimiphos-methyl, dimethoate, phosalone and carbamates - pirimicarb, 
<smiles>CCOP(=O)(OCC)Oc1ccc([N+](=O)[O-])cc1</smiles>

paraoxon ethyl<smiles>CCOP(=S)(OCC)Oc1nc(Cl)c(Cl)cc1Cl</smiles>

chlorpyrifos<smiles>CCOP(=S)(OCC)SCn1c(=O)oc2cc(Cl)ccc21</smiles>
phosalone<smiles>CNC(=O)Oc1cccc2c1CC(C)(C)C2</smiles>

carbofuran<smiles>CCOP(=S)(OCC)Oc1ccc([N+](=O)[O-])cc1</smiles>

parathion ethyl<smiles>COP(=S)(OC)Oc1ccc([N+](=O)[O-])c(C)c1</smiles>

fenitrothion<smiles>CNC(=O)CSP(=S)(OC)OC</smiles>

dimethoate<smiles>CCN(C)C(=O)Oc1cccc(C(C)N(C)C)c1</smiles>

rivastigmine<smiles>COP(=O)(OC)C(O)C(Cl)(Cl)Cl</smiles>

trichlorfon<smiles>CCN(CC)c1nc(C)cc(OP(=S)(OC)OC)n1</smiles>

pirimiphos methyl<smiles>CN(C)C(=O)Oc1ccc[n+](C)c1</smiles>

pyridostigmine<smiles>Cc1nc(N(C)C)nc(OC(=O)N(C)C)c1C</smiles>

pirimicarb

Fig. 4. Selected organophosphate and carbamate inhibitors of cholinesterases.

carbofuran, carbosulfan, methiocarb, fenoxycarb. The structures of selected organophosphate and carbamate compounds are shown below (Fig. 4).

\section{Inhibitors of the $\alpha$-anionic site}

Cholinesterase inhibitors binding to the $\alpha$-anionic site are a group of chemical compounds containing certain common motives. Firstly, these compounds typically contain condensed aromatic cores. Secondly, there should be quarternary ammonium or nitrogen included as a heteroatom. Acrdines and tetrahydroacridines can be mentioned as examples. Quinolines and isoquinolines are other common structures interacting with the $\alpha$-anionic site of cholinesterases. In comparison with the esteratic site inhibitors, compounds interacting with the $\alpha$-anionic site are reversible inhibitors. 9-amino-1,2,3,4,-tetrahydroacridine known as tacrine, which is also considered one of the most important inhibitors of the $\alpha$-anionic site able to suppress Alzheimer's disease manifestation. It is marketed worldwide under the trade name Cognex. The main disadvantage of tacrine is its relatively high hepatotoxicity $^{98}$. There is an effort underway to find less toxic derivatives of tacrine ${ }^{99}$. In the past, 7-methoxytacrine was extensively investigated as a promising substitute to tacrine. This compound is less toxic than tacrine and some in vitro as well as in vivo tests proved superior to tacrine ${ }^{100,101}$. Protoberbrine alkaloids are strong natural inhibitors of AChE. Berberine, palmatine, jatrorrhizine and epiberberine are examples. These substances are considered promising drugs for Alzheimer's disease symptomatic treatment ${ }^{102}$.

Galantamine (Nivalin) is another well known drug interacting with the $\alpha$-anionic site. It is an alkaloid from the Caucasian snowdrop (Galanthus woronowii, Amaryllidaceae). The properties of galantamine were firstly recognized by Mashkovsky and Kruglikova-Lvova in the 1950s (ref. ${ }^{103}$ ). Beside the $\alpha$-anionic site, galantamine also binds at another important part of the AChE active site including aromatic gorge $\mathrm{e}^{104,105}$. The formulas of these compounds are shown in (Fig. 5).

\section{Inhibitors binding into aromatic gorge}

The aromatic gorge is not a typical target for cholinesterase inhibitors. On the other hand, inhibitors interacting with the $\alpha$-anionic site will probably also interact with the aromatic gorge. Galantamine can be mentioned as an example (see above). In silico methods and structural analyses have shown that some bisquarternary compounds such as the depolarizing muscle relaxant decamethonium (Fig. 6) provide a stable complex with 
<smiles>c1ccc2nc3ccccc3cc2c1</smiles>

acridine<smiles>Nc1c2c(nc3ccccc13)CCCC2</smiles>

tacrine<smiles>COc1ccc2nc3c(c(N)c2c1)CCCC3</smiles>

7-methoxytacrine<smiles>c1ccc2ncccc2c1</smiles>

quinoline<smiles></smiles>

berberine<smiles>COc1ccc2c3c1OC1CC(O)C=CC31CCN(C)C2</smiles>

galantamine<smiles>c1ccc2cnccc2c1</smiles>

isoquinoline<smiles>[X][N+]1=Cc2cc3ccc(OC)c(OC)c3cc2-c2cc(OC)c(OC)cc2C1</smiles>

palmatine<smiles>[X][N+]12CCc3cc(O)c(OC)cc3C(=Cc3ccc(OC)c(OC)c3C1)C2</smiles>

jatrorrhizine

Fig. 5. Selected inhibitors that bind onto the $\alpha$-anionic site.

the aromatic gorge due to electrostatic interaction ${ }^{106}$. But the main decamethonium effect is not on $\mathrm{AChE}$ (ref. ${ }^{107}$ ).

\section{Inhibitors of peripheral $(\beta)$ anionic site}

The peripheral anionic site is the main target of many pharmacologically important compounds rather than toxins. Much attention is given to the peripheral anionic site due to the link to Alzheimer's disease. Lack of acetylcholine was considered as a major factor in the cause of Alzheimer's disease (AD). The deposition of amyloid plaque in $\mathrm{AD}$ may be accelerated or even triggered by interaction of $\beta$-amyloid with the peripheral anionic site. Inhibitors binding at the peripheral anionic site are considered not only symptomatic drugs for Alzheimer's disease, but also probably causative ones ${ }^{108}$. It should be emphasized though that the etiology of Alzheimer's disease is not thoroughly understood and the actual function of AChE is still being investigated.

Aflatoxins are natural hepatocarcinogens activated by liver cytochrome P450. They probably interact with<smiles>C[N+](C)(C)CCCCCCCCCC[N+](C)(C)C</smiles>

Fig. 6. Decamethonium (anions are not considered).

the peripheral anionic site. Despite strong inhibition of $\mathrm{AChE}$, it seems that $\mathrm{BuChE}$ has no sensitivity to aflatoxin as shown for aflatoxin B1 (ref. ${ }^{109-111}$ ). Inhibition of $\mathrm{AChE}$ was confirmed after the onset of cholinergic symptoms following aflatoxin exposure ${ }^{112}$. The mechanism of aflatoxin interaction with $\mathrm{AChE}$ is not well-explained and more supporting experiments are needed. Double-stranded DNA fluorescence dyes are also inhibitors of AChE. Propidium ${ }^{113}$ as well as ethydium ${ }^{114}$ are proven inhibitors, binding at the peripheral anionic site. The structure of alfatoxin B1, ethidium and propidium are depicted below (Fig. 7).

The effects of certain ions on AChE remain unclear. Oxidative state III+ aluminum ions have been investigated.<smiles>COc1cc2c(c3oc(=O)c4c(c13)CCC4=O)C1C=COC1O2</smiles>

aflatoxin B1<smiles>CC[n+]1c(-c2ccccc2)c2cc(N)ccc2c2ccc(N)cc21</smiles>

ethidium<smiles>CC[N+](C)(CC)CCC[n+]1c(-c2ccccc2)c2cc(N)ccc2c2ccc(N)cc21</smiles>

propidium

Fig. 7. Selected structures that bind to peripheral anionic site (anions are not considered). 


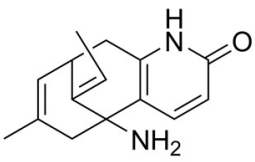

huperzine A

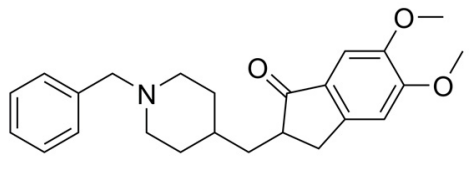

donepezil
Fig. 8. Alzheimer disease drugs binding into peripheral anionic site.

Aluminum can act as a neurotoxin and it has been investigated as the causative agent of Alzheimer's disease for many years; however, no decisive connection has been found ${ }^{115,116}$. Contradictory changes in brain AChE activity after aluminum exposure have been found in different brain regionss ${ }^{117,118}$. On the other hand, $\mathrm{AChE}$ is not only affected by aluminum. Double-valent ions also have the ability to inhibit $\mathrm{AChE}$ activity. Magnesium ions are also an AChE inhibitor ${ }^{119}$.

The peripheral anionic site is a target of newly synthesized drugs for Alzheimer's disease treatment. Inhibition of the peripheral anionic site in Alzheimer's disease has probably not only symptomatic effects due to enhancement of acetylcholine availability. It can also slow down the deposition of amyloid plaque ${ }^{120,121}$. Inhibition of the peripheral anionic site can be considered the most promising for Alzheimer's disease treatment. Drugs that bind at the peripheral (e.g. donepezil, huperzine) as well as at the -anionic site (e.g. tacrine, galantamine) cause elevated expression of AChE. In contrast, inhibitors binding at the esteratic site do not cause significant expression of $\mathrm{AChE}$ ( ref. ${ }^{122}$ ). The up-regulation of $\mathrm{AChE}$ expression is an unwanted effect that lowers treatment efficacy. The commercially available drugs for Alzheimer's disease that inhibit AChE through the peripheral anionic site are e.g. alkaloids huperzine $\mathrm{A}$ as well as $\mathrm{B}$ and man-made donepezil. Huperzine comes from the firmoss Huperzia serrata (Huperziaceae) (ref. ${ }^{123,124}$ ). Huperzine A is a more potent $\mathrm{AChE}$ inhibitor than huperzine B. Huperzine can be isolated from the $H$. serrata that contains above 0.025 (w/w) of huperzine A and less huperzine B; synthetic production is available as well ${ }^{125}$. Donepezil is another drug suitable for Alzheimer's disease treatment with good penetration through the blood brain barrier and slow excretion. It is marketed under the trade name Aricept ${ }^{126}$. The structure of huperzine and donepezil is depicted in (Fig. 8).

\section{CONCLUSION}

Cholinesterases play an important role in the human body. They are a regular target of a large number of toxins including chemical warfare agents. However, the current focus of investigation is development of Myasthenia gravis and Alzheimer's disease drugs. Understanding of cholinesterase structure and the biological mechanism of their inhibition is necessary for novel effective drug development.

\section{REFERENCES}

1. Loewi O. Uberhumerole ubertragbarkeit der herznervenwirkung. I Mitteilung Pflugers Arch 1921;189:239-42.

2. Wessler I, Kirkpatrick CJ. Acetylcholine beyond neurons: the non-neuronal cholinergic system in humans. Br J Pharmacol 2008; 154:1558-71.

3. Bajgar J. Organophosphates/nerve agent poisoning: mechanism of action, diagnosis, prophylaxis, and treatment. Adv Clin Chem 2004;38:151-216.

4. Manoharan I, Boopathy R, DArvesh S, Lockridge O. A medial health report on individuals with silent butyrylcholinesterase in Vysya community of India. Clin Chim Acta 2007;378:128-35.

5. Li B, Duysen EG, Carlson M, Lockridge O. The butyrylcholinesterase knockout mouse as a model for human butyrylcholinesterase deficiency. J Pharmacol Exp Ther 2008;324:1146-54.

6. Duysen EG, Li B, Lockridge O. The butyrylcholinesterase knockout mouse a research tool in the study of drug sensitivity, biodistribution, obesity and Alzheimer's disease. Expert Opin Drug Metab Toxicol 2009;5:523-8.

7. Yen T, Nightingale BN, Burns JC, Sullivan DR, Stewart PM. Butyrylcholinesterase (BCHE) genotyping for post-succinylcholine apnea in an Australian population. Clin Chem 2003;49:1297-1308.

8. Hashim Y, Shepherd D, Wiltshire S, Holman R, Levy JC, Clark A, Cull CA. Butyrylcholinesterase $\mathrm{K}$ variant on chromosome $3 \mathrm{q}$ is associated with Type II diabetes in white Caucasian subjects. Diabetologia 2001;44:2227-30.

9. Holmes C, Ballard C, Lehmann D, Smith AD, Beaumont H, Day IN, Khan MN, Lovestone S, McCulley M, Morris CM, Munoz DG, O’Brien K, Russ C, Del Ser T, Warden D. Rate of progression of cognitive decline in Alzheimer's disease effect of butyrylcholinesterase K gene variation. J Neurol Neurosurg Psychiatry 2005;76:6403.

10. Kallow W, Genest K. A method for the detection of human serum cholinesterase: determnation of dibucaine numbers. Can J Biochem 1957;35:339-46.

11. Iwasaki T, Yoneda M, Nakajima A, Terauchi Y. Serum butyrylcholinesterase is strongly associated with adiposity, the serum lipid profile and insulin resistance. Intern Med 2007;46:1633-9.

12. Ostergaard D, Viby-Moogensen J, Hanel HK, Skovgaard LT. Half-life of plasma cholinesterase. Acta Anaesthesiol Scand 1988;32:266-9.

13. Yuan J, Yin J, Wang E. Characterization of procaine metabolism as probe for the butyrylcholinesterase enzyme investigation by simultaneous determination of procaine and its metabolite using capillary electrophoresis with electrochemiluminescence detection. J Chromatogr A 2007;1154:368-72.

14. Zelinski T, Coghlan G, Mauthe J, Triggs-Raine B. Molecular basis of succinylcholine sensitivity in a prairie Hutterite kindred and genetic characterization of the region containing the BCHE gene. Mol Genet Metab 2007;90:210-16.

15. Duysen EG, Li B, Carlson M, Li YF, Wieseler S, Hinrichs SH, Lockridge $\mathrm{O}$. Increased hepatotoxicity and cardiac fibrosis in cocaine-treated butyrylcholinesterase knockout mice. Basic Clin Pharmacol Toxicol 2008;103:514-21.

16. Kolarich D, Weber A, Pabst M, Stadlmann J, Teschner W, Ehrlich H, Schwarz HP, Altmann F. Glycoproteomic characterization of butyrylcholinesterase from human plasma. Proteomics 2008;8:25463.

17. Saxena A, Sun W, Luo C, Myers TM, Koplovitz I, Lenz DE, Doctor BP. Bioscavenger for protection from toxicity of organophosphorus compounds. J Mol Neurosci 2006;30:145-8.

18. Rozengart EV, Basova NE, Suvorov AA, Khovanskikh AE. Indophenol chromogenic substrates of cholinesterases of different origin. J Evol Biochem Physiol 2002;38:16-23.

19. Grigoryan H, Halebyan G, Lefebvre B, Brasme B, Masson P. Mechanism of hydrolysis of dicholine esters with long polymethylene chain by human butyrylcholinesterase. Biochim Biophys Acta 2008; 1784:1818-24.

20. Saeed A, de Boeck S, Debruyne I, Wouters J, Stockx J. Hen's egg yolk cholinesterase. Purification, characterization and comparison 
with hen's liver and blood plasma cholinesterase. Biochim Biophys Acta 1980;614:389-99.

21. Giacobini E. Cholinesterases: new roles in brain function and in Alzheimer's disease. Neurochem Res 2003;28:515-22.

22. Grigoryan HA, Hambardzumyan AA, Mkrtchyan MV, Topuzyan VO, Halebyan GP, Asatryan RS. Alpha, beta-dehydrophenylalanine choline esters, a new class of reversible inhibitors of human acetylcholiensterse and butyrylcholinesterase. Chem Biol Interact 2008;171:108-16.

23. Debord J, Laubarie C, Dantoine T. Microcalorimetric study of the inhibition of butyrylcholinesterase by carbamates. Anal Biochem 2008;373:247-52.

24. Kamal MA, Klein P, Luo W, Li Y, Holloway HW, Tweedie D, Greig $\mathrm{NH}$. Kinetics of human serum butyrylcholinesterase inhibition by a novel experimental Alzheimer therapeutic, dihydrobenzodioxepine cymserine. Neurochem Res 2008;33:745-53.

25. Nagasawa T, Sugisaki H, Tani Y, Ogata K. Purification and characterization of butyrylcholine-hydrolyzing enzyme from Pseudomonas polycolor. Biochim Biophys Acta 1976;429:817-27.

26. Monteiro M, Quintaneiro C, Morgado F, Soares AM, Guilhermino L. Characterization of the cholinesterases present in head tissues of the estuarine fish Pomatoschistus microps: application to biomonitoring. Exotoxicol. Environ. Saf. 2005;62:341-7.

27. Plageman LR, Puletti GM, Skau KA. Characterization of acetylcholinesterase in Caco-2 cells. Exp Biol Med (Maywood) 2002;227:480-6.

28. Zhukovskii YG. On establishment of individuality of the choliensterase enzyme in the studied preparation. J Evol Biochem Physiol 2003;39:281-90

29. Blong RM, Bedows E, Lockridge O. Tetramerization domain of human butyrylcholinesterase is at the C-terminus. Biochem J 1997;327:747-57.

30. Lockridge O, Bartels CF, Vaughan TA, Wong CK, Norton SE, Johnson LL. Complete amino acid sequene of human serum cholinesterase. J Biol Chem 1987;262:549-57.

31. Masson P, Nachon F, Bartels CF, Froment MT, Ribes F, Matthews $\mathrm{C}$, Lockridge $\mathrm{O}$. High activity of human butyrylcholinesterase at low $\mathrm{pH}$ in the presence of excess butyrylthiocholine. Eur J Biochem 2003;270:315-24.

32. Nicolet Y, Lockridge O, Masson P, Fontecilla-Camps JC, Nachon F. Crystal structure of human butyrylcholinesterase and of its complexes with substrate and products. J Biol Chem 2003;278:41141-7.

33. Fujii T, Mori Y, Tominaga T, Hayasaka I, Kawashima K. Maintenance of constant blood acetylcholine content before and after feeding in young chimpanzees. Neurosci Lett 1997;227:21-4.

34. Fukuto TR. Mechanism of action of organophosphorus and carbamate insecticides. Environ Health Perspect 1990;87:245-54.

35. Vignaud A, Fougerousse F, Mousel E, Guerchet N, Hourde C, Bacou F, Butler-Browne GS, Chatonnet A, Ferry A. Genetic inactivation of acetylcholinesterase causes functional and structural impairment of mouse soleus muscles. Cell Tissue Res 2008:333:289-96.

36. Hartmann J, Kiewert C, Duysen EG, Lockridge O, Greig NH, Klein J. Excessive hippocampal acetylcholine levels in acetylcholinesterase-deficient mice are moderated by butyrylcholinesterase activity. J Neurochem 2007;100:1421-9.

37. Sussman JL, Harel M, Frolow F, Oefner C, Goldman A, Toker L, Silman I. Atomic structure of acetylcholinesterase from Torpedo californica: a prototypic acetylcholine-binding protein. Science 1991;253:872-9.

38. Ollis DL, Cheah E, Cygler M, Dijkstra B, Frolow F, Franken SM, Harel M, Remington SJ, Silman I, Schrag J, Sussman JL, Verschueren KHG, Goldman A. The $\alpha / \beta$ hydrolase fold. Protein Eng 1992;5:197-211.

39. Cygler M, Schrag JD, Sussman JL, Harel M, Silman I, Gentry MK, Doctor BP. Relationship between sequence conservation and three-dimensional structure in a large family of esterases, lipases, and related proteins. Protein Sci 1993;2:366-82.

40. Brenner S. The molecular evolution of genes and proteins: a tale of two serines. Nature 1988;334:528-30.

41. Silman I, Sussman JL. Acetylcholinesterase: how is structure related to function? Chem Biol Interact 2008;175:3-10.
42. Kovarik Z, Radic Z, Berman HA, Simeon-Rudolf V, Reiner E, Taylor P. Acetylcholinesterase active centre and gorge conformations analysed by combinatorial mutations and enantiomeric phosphonates. Biochem J 2003;373:33-40.

43. Bartolucci C, Haller LA, Jardis U, Fels G, Lamba D. Probing Torpedo californica acetylcholinesterase catalytic gorge with two novel bis-functional galanthamine derivatives. J Med Chem 2010;53:745-51.

44. Kreienkamp HJ, Weise C, Raba R., Aaviksaar A, Hucho F. Anionic subsites of the catalytic center of acetylcholinesterase from Torpedo and from cobra venom. Proc Natl Acad Sci USA 1991;88:6117-21.

45. Ripoll DR, Faerman CH, Axelsen PH, Silman I, Sussman JL. An electrostatic mechanism for substrate guidance down the aromatic gorge of acetylcholinesterase. Proc Natl Acad Sci USA 1993;90:5128-32.

46. Koellner G, Steiner T, Millard CB, Silman I, Sussman JL. A neutral molecule in a cation-binding site: specific binding of a PEG$\mathrm{SH}$ to acetylcholinesterase from Torpedo californica. J Mol Biol 2002;320:721-5.

47. Changeux JP. Responses of acetylcholinesterase from Torpedo marmarata to salts and curarizing drugs. Mol Pharmacol 1996;2:36992.

48. Johnson G, Moore SW. The peripheral anionic site of acetylcholinesterase: structure, functions and potential role in rational drug design. Curr Pharm Des 2006;12:217-25.

49. Haviv H, Wong DM, Silman I, Sussman JL. Bivalent ligands derived from Huperzine A as acetylcholinesterase inhibitors. Curr Top Med Chem 2007;7:375-87.

50. Eichler J, Anselment A, Sussman JL, Massoulie J, Silman I. Differential effects of „peripheral“site ligands on Torpedo and chicken acetylcholinesterase. Mol Pharmacol 1994;45:335-40.

51. Inestrosa NC, Dinamarca MC, Alvarez A. Amyloid-cholinesterase interactions. Implications for Alzheimer's disease. FEBS J 2008;275:625-32.

52. Chatonnet A, Lockridge O. Comparison of butyrylcholinesterase and acetylcholinesterase. Biochem J 1989;260:625-34.

53. Andres C, elMourabit M, Stutz C, Mark J, Waksman A. Are soluble and membrane-bound rat brain acetlcholinesterase different? Neurochem Res 1990;15:1065-72.

54. Fernandez HL, Moreno RD, Inestrosa NC. Tetrameric (G4) acetylcholinesterase: structure, localization, and physiological regulation. J Neurochem 1996;66:1335-46.

55. Inestrosa NC, Roberts WL, Marshall TL, Rosenberry TL. Acetylcholinesterase from bovine caudate nucleus is attached to membranes by a novel subunit distinct from those of acetylcholinesterases in other tissues. J Biol Chem 1987;262:4441-4.

56. Mehlert A, Varon L, Silman I, Homans SW, Ferguson MAJ. Structure of the glycosyl-phosphatidylinositol membrane anchor of acetylcholinesterase from the electric organ of the electric-fish, Torpedo californica. Biochem J 1993;296:473-9.

57. Rosenberry TL, Roberts WL, Haas R. Glycolipid membrane-binding domain of human erythrocyte acetylcholinesterase. Fed Proc 1986; 45:2970-5

58. Liao J, Norgaard-Pedersen B, Brodbeck U. Subunit association and glycosylation of acetylcholinesterase from monkey brain. $\mathrm{J}$ Neurochem 1993;61:1127-34.

59. Massoulie J, Bon S. The molecular forms of cholinesterse and acetylcholinesterase in verterbrates. Ann Rev Neurosci 1982;5:57-106.

60. Feng G, Krejci E, Molgo J, Cunningham JM, Massoulie J, Sanes JR. Genetic analysis of collagen Q: roles in acetylcholinesterse and butyrylchoilnesterase assembly and in synaptic structure and function. J Cell Biol 1999;144:1349-60.

61. Harel M, Sussman JL, Krejci E, Bon S, Chanal P, Massoulie J, Silman I. Conversion of acetylcholinesterase to butyrylcholinesterase: modeling and mutagenesis. Proc Natl Acad Sci USA 1992;89:10827-31.

62. Haigh JR, Johnston SR, Peppernay A, Mattern PJ, Garcia GE, Doctor BP, Gordon RK, Aisen PS. Protection of red blood cell acetylcholinesterase by oral huperzine A against ex vivo soman exposure: next generation prophylaxis and sequestering of acetylcholinesterase over butyrylcholinesterase. Chem Biol Interact 2008; 175:380-6. 
63. Ahmed M, Rocha JB, Correa M, Mazzanti CM, Zanin RF, Morschi AL, Morsch VM, Schetinger MR. Inhibition of two different cholinesterases by tacrine. Chem Biol Interact 2006;162:165-71.

64. Pohanka M, Jun D, Kuca K. Amperometric biosensor for evaluation of competitive cholinesterase inhibition by the reactivator HI-6. Anal Lett 2007;40:2351-9.

65. Pohanka M, Musilek K, Kuca K. Progress of biosensors based on cholinesterase inhibition. Curr Med Chem 2009;16:1790-8.

66. Bartling A, Worek F, Szinicz L, Thiermann H. Enzyme-kinetic investigation of different sarin analogues reacting with human acetylcholinesterase and butyrylcholinesterase. Toxicology 2007;233:166-72.

67. Tecles F, Ceron JJ. Determination of whole blood cholinesterase in different animal species using specific substrates. Res Vet Sci 2001;70:233-8.

68. Rosenberry TL. Catalysis by acetylcholinesterase: evidence that the rate-limitng step for acylation with certain substrates general acid-base catalysis. Proc Natl Acad Sci USA 1975;72:3834-8.

69. Krupka RM. The mechanism of action of acetylcholinesterase: substrate inhibition and the binding of inhibitors. Biochemistry 1963;2:76-82.

70. Reed MC, Lieb A, Nijhout HF. The biological significance of substrate inhibition: a mechanism with diverse functions. Bioassays 2010;32:422-9.

71. Guedes RN, Zhu KY, Kambhampati S, Dover BA. Characterization of acetylcholinesterase purified from the lesser grain borer, Rhyzopertha dominica (Coleoptera: Bostrichidae). Comp Biochem Physiol C Pharmacol Toxicol Endocrinol 1998;119:205-10.

72. Gao JR, Zhu KY. An acetylcholinesterase purified from the greenbug (Schizaphis graminum) with some unique enzymological and pharmacological characteristics. Insect Biochem Mol Biol 2001;31:1095-104.

73. Paraoanu LE, Layer PG. Acetylcholinesterase in cell adhesion, neurite growth and network formation. FEBS J 2008;275:618-24.

74. Johnson G, Swart C, Moore SW. Non-enzymatic developmental functions of acetylcholiensterase - the question of redundancy. FEBS J 2008;275:519-38.

75. Adler M, Filbert MG. Role of butyrylcholinesterase in canine tracheal smooth muscle function. FEBS Lett 1990;267:107-10.

76. Villarroya M, Garcia AG, Marco JL. New classes of AChE inhibitors with additional pharmacological effects of interests for the treatment of Alzheimer's disease. Curr Pharm Des 2004;10:3177-84.

77. Giacobini E. Selective inhibitors of butyrylcholinesterase: a valid alternative for therapy of Alzheimer's disease? Drugs Aging 2001;18:891-8.

78. Giacobini E. Cholinesterase inhibitors: new roles and therapeutic alternatives. Pharmacol Res 2004;50:433-40.

79. Weiner L, Shnyrov VL, Konstantinovskji L, Roth E, Ashani Y, Silman I. Stabilization of Torpedo californica acetylcholinesterase by reversible inhibitors. Biochemisty 2009;48:563-74.

80. Millard CB, Kryger G, Ordentlich A, Greenblatt HM, Harel M, Raves ML, Segall Y, Barak D, Shafferman A, Silman I, Sussman JL. Crystal structures of aged phosphonylated acetylcholinesterase: nerve agent reaction products at the atomic level. Biochemistry 1999;38:7032-9.

81. Barak D, Ordentlich A, Stein D, Yu QS, Greig NH, Shafferman A. Accomodation of physostigmine and its analogues by acetylchoilnesterase is dominated by hydrophobic interactions. Biochem $\mathrm{J}$ 2009;417:213-22.

82. Schaltz F. Neurosciences and research on chemical weapons of mass destruction in Nazi Germany. J Hist Neurosci 2006;15:186209.

83. Kuca K, Pohanka M. Chemcial warfare agents. EXS 2010; 100:543-58.

84. Jovanovic D. The effect of bispyridinium oximes on neuromuscular blockade induced by highly toxic organohposhates in rat. Archives Internationales de Pharmacodynamie et de Therapie 1983;262:231-41.

85. Brimblecomb RW, Green DM, Stratton JA, Thompson PB. The protective actions of some anticholinergic drugs in sarin poisoning. Brit J Pharmacol 1970;39:822-30.

86. Boskovic B, Kovacevic V, Jovanovic D. 2-PAM chloride HI6 and HGG12 in soman and tabun poisoning. Fund Appl Toxicol 1984; $4: 106-15$.
87. Rengstorff RH. Accidental exposure to sarin: vision effects. Arch Toxicol 1985;56:201-3.

88. Chilcott RP, Dalton CH, Hill I, Davison CM, Blohm KL, Clarkson ED, Hamilton MG. In vivo skin absorption and distribution of the nerve agent VX (O-ethyl-S-[2(diisopropylamino)ethyl] methylphosphonothioate) in the domestic white pig. Hum Exp Toxicol 2005;24:347-52.

89. Hemmer AC, Otto TC, Wierdl M, Edwards CC, Fleming CD, MacDonald M, Cashman JR, Potter PM, Cerasoli DM, Redinbo MR.. Human carboxylesterase 1 stereoselectively binds the nerve agents cyclosarin and spontaneously hydrolyzes the nerve agent sarin. Mol Pharmacol 2010;77:508-16.

90. Kanamori-Kataoka M, Seto Y. Paraoxonase activity against nerve gases measured by capillary electrophoresis and characterization of human serum paraoxonase (PON1) polymorphism in the coding region (Q192R). Anal Biochem 2009;385:94-100.

91. Kasagami T, Miyamoto T, Yamamoto I. Activated transformations of organophoshorus insecticides in the case of non-AChE inhibitory oxons. Pest Manag Sci 2002;58:1107-17.

92. Haigh JR, Adler M, Apland JP, Desphpande SS, Barham CB, Desmond P, Koplovitz I, Lenz DE, Gordon RK. Protection by pyridostigmine bromide of marmoset hemi-diaphragm acetylcholinesterase activity after soman exposure. Chem Biol Interact, In press.

93. Andersen JB, Engeland A, Owe JF, Gilhus NE. Myasthenia gravis requiring pyridostigmine treatment in a national population cohort. Eur J Neurol, In press.

94. Darvesh S, Darvesh KV, McDonald RS, Mataija D, Walsh R, Mothana S, Lockridge O, Martin E. Carbamates with differential mechanism of inhibition toward acetylchoilnesterase and butyrylcholinesterase. J Med Chem 2008;51:4200-12.

95. Friedman A, Kaufer D, Shemer J, Hendler I, Soreq H, Tur-Kaspa I. Pyridostigmine brain penetration under stress enhances neuronal excitability and induces early immediate transcriptional response. Nat Med 1996;2:1382-5.

96. Chitnis S, Rao J. Rivastigmine in Parkinson's disease dementia. Expert Opin Drug Metab Toxicol 2009;5:941-55.

97. Cummings JL, Nadel A, Masterman D, Cyrus PA. Efficacy of metrifonate in imporving the psychiatric and behavioral disturbances of patients with Alzheimer's disease. J Geriatr Psychiatry Neurol 2001; $14: 101-8$.

98. Alfirevic A, Mills T, Carr D, Barratt BJ, Jawaid A, Sherwood J, Smith JC, Tugwood J, Hartkoorn R, Owen A, Park KB, Pirmohamed M. Tacrine-induced liver damage: an analysis of 19 candidate genes. Pharmacogenet Genomics 2007;17:1091-100.

99. Tumiatti V, Minarini A, Bolognesi ML, Milelli A, Rosini M, Melchiorre C. Tacrine derivatives and Alzheimer's disease. Curr Med Chem 2010;17:1825-38.

100. Bajgar J, Bisso GM, Michalek H. Differential inhibition of rat brain acetylcholinesterase molecular forms by 7-methoxytacrine in vitro. Toxicol Lett 1995;80:109-14.

101. Pohanka M, Kuca K, Kassa J. New performance of biosensor technology for Alzheimer's disease drugs: in vitro comparison of tacrine and 7-methoxytacrine. Neuroendocrinol Lett 2008;29:7558.

102. Jung HA, Min BS, Yokozawa T, Lee JH, Kim YS, Choi JS. AntiAlzheimer and antioxidant activities of Coptidis Rhizoma alkaloids. Biol Pharm Bull 2009;32:1433-8.

103. Mashkovsky MD, Kruglikova-Lvova RP. On the pharmacology of the new alkaloid galantamine. Farmakologia Toxicologia (Moscow) 1951;14:27-30.

104. Bartolucci C, Perola E, Pilger C, Fels G, Lamba D. Threedimensional structure of a complex of galanthamine (Nivalin) with acetylcholinesterase from Torpedo californica: implications for the design of new anti-Alzheimer drugs. Proteins 2001;42:18291.

105. Pilger C, Bartolucci C, Lamba D, Tropsha A, Fels G. Accurate prediction fo the bound conformation of galanthamine in the active site of Torpedo californica acetylcholinesterase using molecular docking. J Mol Graph Model 2001;19:288-96.

106. Axelsen PH, Harel M, Silman I, Sussman JL. Structure and dynamics of the active site gorge of acetylcholinesterase: synergistic 
use of molecular dynamics simulation and X-ray crystallography. Protein Sci 1994;3:188-97.

107. Riker WF, Okamoto M, Artusio JF. In vivo reversal of depolarizing neuromuscular blockade. Arch Int Pharmacodyn Ther 1995;330:90-101.

108. Castro A, Martinez A. Targeting beta-amyloid pathogenesis through acetylchoinesterase inhibitors. Curr Pharm Des 2006;12:4377-87.

109. Hansmann T, Sanson B, Stojan J, Weik M, Marty JL, Fournier D. Kinetic insight into the mechanism of cholinesterase inhibition by aflatoxin B1 to develop biosensors. Biosens Bioelectron 2009;24:2119-24.

110. Pohanka M, Musilek K, Kuca K. Evaluation of aflatoxin B1 acetylcholinesterase dissociation kinetic using the amperometric biosensor technology: prospect for toxicity mechanism. Protein Pept Lett 2010;17:340-2.

111. Pohanka, M, Kuca K, Jun D. Aflatoxin assay using an amerometric sensor strip and acetylcholinesterase as recognition element. Sens Lett 2008;6:450-3.

112. Egbunike GN, Ikegwuonu FI. Effect of aflatoxicosis on acetylcholinesterse activity in the brain and adenohypophysis of the male rat. Neurosci Lett 1984;52:171-4.

113. Cavalli A, Bottegoni G, Raco C, De Vivo M, Recanatini M. A computational study of the binding of propidium to the peripheral anionic site of human acetylcholinesterase. J Med Chem 2004:47:3991-9.

114. Mazzanti CM, Spanevello RM, Obregon A, Pereira LB, Streher CA, Ahmed M, Mazzanti A, Graca DL, Morsch VM, Schetinger MR. Ethidium bromide inhibits rat brain acetylcholinesterase activity in vitro. Chem Biol Interact 2006;162:121-7.

115. Drago D, Bolognin S, Zatta P. Role of metal ions in the abeta oligomerization in Alzheimer's disease and in other neurological disorders. Curr Alzheimer Res 2008;5:500-7.

116. Jansson ET. Aluminum exposure and Alzheimer's disease. J Alzheimers Dis 2001;3:541-9.
117. Kaizer RR, Correa MC, Spanevello RM, Morsch VM, Mazzanti CM, Goncalves JF, Schetinger MR. Acetylcholinesterase activation and enhanced lipid peroxidation after long-term exposure to low levels of aluminum on different mouse brain regions. J Inorg Biochem 2005;99:1865-70.

118. Kaizer RR, Correa MC, Gris LR, da Rosa CS, Bohrer D, Morsch VM, Schetinger MR. Effect of long-term exposure to aluminum on the acetylcholinesterase activity in the central nervous system and erythrocytes. Neurochem Res 2008;33:2294-2301.

119. Inestrosa NC, Perez CA, Simpfendorfer RW. Sensitivity of acetylcholinesterase molecular forms to inhibition by high $\mathrm{MgCl}_{2}$ concentration. Biochim Biophys Acta 1994;1208:286-93.

120. Arce MP, Rodriguez-Franco MI, Gonzalez-Munoz GC, Perez C, Lopez B, Villaroya M, Lopez MG, Garcia AG, Conde S. Neuroprotective and cholinergic properties of multifunctional glutamic acid derivatives for the treatment of Alzeheimer's disease. J Med Chem 2009;52:7249-57.

121. Berson A, Knobloch M, Hanan M, Diamant S, Sharoni M, Schuppli D, Geyer BC, Ravid R, Mor TS, Nitsch RM, Soreg H. Changes in readthrough acetylcholinesterase expression modulate amyloid-beta pathology. Brain 2008;131:109-19.

122. Darreh-Shori T, Soininen H. Effects of cholinesterse inhibitors on the activities and protein levels of cholinesterases in the cerebrospinal fluid of patients with Alzheimer's disease: a review of recent clinical studies. Curr Alzheimer Res 2010;7:67-73.

123. Gao X, Zheng CY, Yang L, Tang XC, Zhang HY. Huperzine A protects isolated rat brain mitochondria against beta-amyloid peptide. Free Radic Biol Med 2009; 46:1454-62.

124. Zhang HY, Tang XC. Huperzine B, a novel acetylcholinesterase inhibitor, attenuates hydrogen peroxide induced injury in PC12 cells. Neurosci Lett 2000;292:41-44.

125. Bai D. Development of huperzine A and B for treatment of Alzheimer's disease. Pure Appl Chem 2007;79:469-79.

126. Kryger G, Silman I, Sussman JL. Three-dimensional structure of a complex of E2020 with acetylcholinesterase from Torpedo californica. J Physiol Paris 1998;92:191-4. 
